\title{
Calcitonin inhibits osteoclast formation in mouse haematopoetic cells independently of transcriptional regulation by receptor activator of NF- $\kappa B$ and c-Fms
}

\author{
Susanne Granholm, Pernilla Lundberg and UIf H Lerner \\ Department of Oral Cell Biology, Umeå University, S-901 87 Umeå, Sweden \\ (Correspondence should be addressed to U H Lerner; Email: ulf.lerner@odont.umu.se)
}

\begin{abstract}
The effects of calcitonin (CT) on osteoclast formation and gene expression have been studied in cultured mouse spleen cells and mouse bone marrow macrophages (BMMs). CT inhibited the formation of multinucleated osteoclasts and resorption pits in spleen cell cultures and BMM as well as in $\mathrm{CD}_{11} 5^{+} \mathrm{CD}^{-}$ $\mathrm{CD} 45 \mathrm{R}^{-}$sorted BMM cultures, incubated in the presence of macrophage colony-stimulating factor and receptor activator of NF- $\kappa B$ ligand (RANKL). No effect on apoptosis by CT was observed. CT did not affect the mRNA expressions of RANK and c-Fms, or the mRNA expressions of a wide variety of transcription factors and genes important for osteoclast differentiation and activity. CT induced inhibition of tartrateresistant acid phosphatase (TRAP), positive multinucleated osteoclast formation was not associated with any decrease of total TRAP activity, resulting in a large number of $\mathrm{TRAP}^{+}$
\end{abstract}

mononucleated cells in CT-treated cultures. CT did not affect the mRNA expression of dendritic cell-specific transmembrane protein, $\mathrm{d} 2$ isoform of vacuolar $\left(\mathrm{H}^{+}\right)$ATPase $\mathrm{v}_{\mathrm{o}}$ domain, a disintegrin and metalloproteinase domain 8 (ADAM8), ADAM12, DNAX-activating protein or Fc receptor common $\gamma$ chain suggested to be involved in fusion of mononucleated osteoclast progenitor cells. The inhibitory effect by CT was mimicked not only by compounds activating cAMP and protein kinase A (PKA) but also by a cAMP analogue activating the exchange protein directly activated by cAMP (Epac) pathway. It is concluded that CT, through cAMP/PKA/Epac cascades, inhibits osteoclast formation and that this effect is not associated with decreased transcription of genes known to be important for osteoclast progenitor cell differentiation, fusion or function.

Journal of Endocrinology (2007) 195, 415-427

\section{Introduction}

Calcitonin (CT) is a 32-amino acid peptide belonging to a small family of peptides also including $\alpha$-CT gene-related peptide ( $\alpha$-CGRP), $\beta$-CGRP, amylin, adrenomedullin, intermedin and $\mathrm{CT}$ receptor-stimulating peptide (Wimalawansa 1997, Katafuchi et al. 2000, 2003, 2004, Chang et al. 2004, Roh et al. 2004). CT was discovered as an acute hypocalcaemic hormone released from the parathyroid glands (Copp \& Cheney 1962), but shortly thereafter shown to be secreted by thyroid C-cells (Foster et al. 1964, Zaidi et al. 2002). The hypocalcaemic response is mainly due to inhibition of bone resorption (Friedman \& Raisz 1965), caused by activation of CT receptors (CTRs) in mature osteoclasts leading to contraction, ceased motility and decreased bone-resorbing activity (Chambers et al. 1984).

The CTR is expressed in several cells including cells in the central nervous system, in renal epithelial cells and abundantly in mature osteoclasts (Nicholson et al. 1986, Findlay \& Sexton 2004). Early osteoclast progenitor cells do not express CTRs; the expression of CTRs is induced in the mononucleated osteoclast progenitor cells late during differentiation (Lee et al. 1995, Quinn

et al. 1999). Several isoforms of the CTR have been cloned (Lin et al. 1991, Goldring et al. 1993) and found to be members of the seven-transmembrane G-protein-coupled receptor superfamily. CTR is coupled to $G \alpha$ and $G \alpha_{\mathrm{q}}$ proteins and downstream signalling has been linked to both adenylate cyclase-cAMPprotein kinase $\mathrm{A}$ (PKA) and $\mathrm{Ca}^{2+} /$ protein kinase $\mathrm{C}$ (Purdue et al. 2002). CT has also been shown to stimulate the phosphorylation of the mitogen-activated protein kinase extracellular signalregulated protein kinase (ERK1/2) in HEK293 stably expressing the rabbit CTR C1a (Chen et al. 1998) as well as in rabbit and murine osteoclasts (Zhang et al. 2002).

The physiological role of $\mathrm{CT}$ as an inhibitor of bone resorption has recently been challenged by the findings that mice deficient in the gene encoding CT, and the tissue-specific splice variant $\alpha$-CGRP, do not exhibit decreased bone mass because of increased bone resorption, as expected, but instead the opposite, namely increased bone mass due to enhanced bone formation (Hoff et al. 2002). Similarly, heterozygous CTRdeficient mice exhibit increased bone mass (Dacquin et al. 2004). The increased bone mass observed in CT/ $\boldsymbol{\alpha}$-CGRP-deficient mice is due to the absence of CT as shown by the fact that mice selectively lacking $\alpha$-CGRP exhibit osteopenia caused by 
decreased bone formation (Schinke et al. 2004). In contrast, inactivation of the amylin gene leads to decreased bone mass due to increased bone resorption which indicates that amylin may be a more important regulator of physiological bone resorption than CT (Dacquin et al. 2004).

Although mature osteoclasts express CTR and respond to $\mathrm{CT}$, much less is known about effects of CT on osteoclast differentiation. Mononucleated osteoclast progenitor cells have a haematopoietic origin and are most closely related to the monocyte/macrophage precursor cells (Takahashi et al. 2002). Activation of the c-Fms receptor on these cells by macrophage colony-stimulating factor (M-CSF), released by stromal cells, or osteoblasts, upon stimulation by osteoclastforming hormones or cytokines, leads to expansion of the precursor pool of osteoclast progenitor cells and increased cell survival through an anti-apoptotic signal. In addition, increased expression of receptor activator of NF- $\kappa B$ ligand (RANKL), by stromal cells or osteoblasts, stimulates its cognate receptor RANK on the osteoclast progenitor cells causing an unique osteoclast differentiation signal (Teitelbaum 2000, Boyle et al. 2003, Teitelbaum \& Ross 2003, Lerner 2004, Asagiri \& Takayanagi 2007).

Osteoclastogenesis also involves activation of immunoreceptor tyrosine-based activation motif (ITAM)-dependent calcium signalling in osteoclast progenitor cells (reviewed by Asagiri \& Takayanagi 2007). ITAM domains are present in the $\mathrm{Fc}$ receptor common $\gamma$ chain $(\mathrm{FcR} \gamma)$ and DNAX-activating protein (DAP12) which are essential for osteoclastogenesis. $\mathrm{FcR} \gamma$ and DAP12 associate with different ligand-recognizing immunoglobulin-like receptors such as osteoclast-associated receptor (OSCAR), paired immunoglobulin-like receptor A (PIR-A), triggering receptor expressed in myeloid cells (TREMs) and signal-regulatory protein $\beta 1$ (SIRP $\beta 1$ ), of which several have been found to be expressed in osteoclast progenitor cells. The critical role of these co-stimulatory signals is demonstrated by the finding that $F c R \gamma^{-1-}$, $D A P 12^{-/-}$mice are osteopetrotic and lack osteoclasts (Koga et al. 2004, Mócsai et al. 2004). Recently, dendritic cell-specific transmembrane protein (DC-STAMP) has been found to be highly upregulated during osteoclastogenesis and suggested to be important in osteoclast progenitor cell fusion (Rho et al. 2002, Yagi et al. 2006). In addition, the $\mathrm{d} 2$ isoform of vacuolar $\left(\mathrm{H}^{+}\right)$ATPase $\mathrm{v}_{\mathrm{o}}$ domain (Atp6v0d2) has been associated with osteoclast fusion, since Atp6v0d2-deficient mice cannot form multinucleated osteoclast whereas the expression of several osteoclast differentiation genes was unaffected (Lee et al. 2006).

Studies on effects by CT on osteoclast differentiation are limited. CT has been found to inhibit parathyroid hormone (PTH)-stimulated multinucleated cell formation in feline marrow-derived mononuclear cell cultures (Ibbotson et al. 1984) and $\mathrm{D}_{3}$-stimulated multinuclear cell formation in primate marrow mononuclear cell cultures (Roodman et al. 1985). More recently, Cornish et al. (2001) have shown that CT, concentration dependently, inhibits osteoclast formation in stromal cell containing mouse bone marrow cultures stimulated by $\mathrm{D}_{3}$. In the present investigation, we have studied the effects of CT on osteoclastogenesis in M-CSF- and RANKL-stimulated mouse spleen cell and mouse bone marrow macrophage (BMM) cultures and using gene expression analyses studied the effect of CT on osteoclast progenitor cell differentiation. In addition, intracellular signalling pathways mediating the effect of CTwere studied. We found CT, through cAMP/PKA/exchange protein directly activated by cAMP (Epac) cascades, to be a potent inhibitor of osteoclast formation by a direct effect on osteoclast progenitor cells, but to be without effect on the mRNA expression of a wide variety of different genes known to be important for osteoclast differentiation, fusion and function.

\section{Materials and Methods}

\section{Experimental animals}

CsA mice from our own inbred colony were used in all experiments. Animal care and experiments were approved and conducted in accordance with accepted standards of humane animal care and use as deemed appropriate by the Animal Care and Use Committee of Umeå University, Umeå, Sweden.

\section{Materials}

Materials used are presented as supplementary data (see supplementary data in the online version of the Journal of Endocrinology at http://joe.endocrinology-journals.org/ content/vol195/issue 3/).

\section{Spleen cell cultures}

Cells were obtained from spleens of 5- to 9-week-old mice. The spleens were dissected free of adhering tissues, and cells were released by rubbing the spleens against the bottom of a Petri dish, in which grooves had been made by a scalpel. Erythrocytes were lysed in red blood cell lysis buffer $\left(0 \cdot 16 \mathrm{M} \mathrm{NH}_{4} \mathrm{Cl}, 0 \cdot 17 \mathrm{M}\right.$ Tris, $\mathrm{pH} 7 \cdot 65)$ and the remaining cells were seeded, at a cell density of $10^{6} \mathrm{cells} / \mathrm{cm}^{2}$, on plastic coverslips placed in 24-well plates. The cells were cultured in $0.5 \mathrm{ml} \alpha$-minimal essential medium $(\alpha$-MEM) supplemented with $10 \%$ fetal bovine serum (FBS), L-glutamine $(0.7 \mathrm{mM}), 100 \mathrm{U} / \mathrm{ml}$ benzylpenicillin, $100 \mu \mathrm{g} / \mathrm{ml}$ streptomycin and $100 \mu \mathrm{g} / \mathrm{ml}$ gentamycin sulphate. Cells were allowed to settle overnight in complete medium and thereafter the medium was changed and the experiment started. Osteoclast precursor cells were induced to proliferate and differentiate by the addition of M-CSF $(25 \mathrm{ng} / \mathrm{ml})$ and RANKL $(100 \mathrm{ng} / \mathrm{ml})$. To study the effect of salmon CT (sCT) on osteoclastogenesis, cells were grown in medium containing $\mathrm{sCT}$ at different concentrations, together with M-CSF and RANKL. Cells cultured in complete medium without M-CSF and RANKL were included in all experiments as a control. Medium was changed after 3 days. After 1-6 days, the cells were washed three times with PBS (pH 7.35) and fixed with acetone in citrate buffer $/ 3 \%$ formaldehyde solution. Cells were then stained for 
tartrate-resistant acid phosphatase (TRAP) activity using the Sigma Diagnostics Acid Phosphatase Leukocyte staining kit and by following the manufacturer's instruction. Multinucleated (no. of nuclei $\geq 3$ ), TRAP-positive cells were counted as osteoclasts $\left(\mathrm{TRAP}^{+}{ }_{-\mathrm{MuOCL}}\right.$ ). Osteoclasts formed in the spleen cell cultures stimulated by M-CSF and RANKL were able to form pits when cultured on slices of devitalised bovine bone and the stimulation of osteoclastogenesis was associated with increased mRNA expression of several osteoclast genes including $c t r$, trap and cathepsin K (data not shown; present study). No osteoclasts were formed when cells were treated with either M-CSF or RANKL alone and the stimulation caused by M-CSF and RANKL was abolished by osteoprotegerin (OPG; data not shown). No osteoclasts were formed in the presence of PTH or $1,25(\mathrm{OH})_{2}$-vitamin D3 ( $\mathrm{D}_{3}$; data not shown), indicating the lack of stromal cells in the spleen cell cultures.

\section{Bone marrow macrophage cultures}

Highly purified BMMs were isolated according to Takeshita et al. (2000). These cells did not express alkaline phosphatase, RANKL, OPG or CTR mRNA, but mRNA for RANK, c-Fms, cathepsin $\mathrm{K}$ and TRAP, as assessed by quantitative real-time PCR (data not shown).

For osteoclastogenesis experiments, BMMs were seeded either on $0.8 \mathrm{~cm}^{2}$ glass chamber slides or $0.32 \mathrm{~cm}^{2} 96$-well plates at a density of $10^{4}$ cells $/ \mathrm{cm}^{2}$ in $\alpha-\mathrm{MEM} / 10 \% \mathrm{FBS}$ containing either $100 \mathrm{ng} / \mathrm{ml}$ M-CSF (controls) or $100 \mathrm{ng} / \mathrm{ml}$ $\mathrm{M}-\mathrm{CSF}+50 \mathrm{ng} / \mathrm{ml} \mathrm{RANKL}$, with and without $\mathrm{sCT}$ or human CT (hCT), 6-MB-cAMP, 8-pMeOPT-2'-o-cAMP, 8-bromo- $5^{\prime}$-AMP or forskolin.

After 4-5 days, with a change of medium after 3 days, the cultures were harvested and the cells fixed with acetone in citrate buffer $/ 3 \%$ formaldehyde and subsequently stained for TRAP. The TRAP-positive cells with three or more nuclei were considered osteoclasts, and the number of multinucleated osteoclasts was counted $\left(\mathrm{TRAP}^{+}{ }_{-\mathrm{MuOCL}}\right.$ ). Osteoclasts formed in these cultures stimulated by M-CSF and RANKL were able to form pits when cultured on slices of bovine bone and osteoclast formation was associated with increased mRNA expression of CTR, TRAP and cathepsin $\mathrm{K}$. Osteoclasts were not formed in the presence of PTH or $\mathrm{D}_{3}$, indicating the lack of stromal cells in the cultures. Osteoclast formation caused by M-CSF and RANKL was abolished by OPG (data not shown).

\section{Fluorescence-activated cell sorting (FACS)}

Crude bone marrow and BMM cells, obtained (by culturing bone marrow cells for 6 days in the presence of M-CSF) as described above, were washed with $\mathrm{PBS} / 3 \%$ FBS and stained with antibodies $\left(0.4 \mu \mathrm{g} / 10^{6}\right.$ cells) against the macrophage markers mouse CD11b and CD115, or the lymphoid cell markers CD3e and CD45R. The cells were then analysed using a flow cytometer (FACS Calibur; Becton Dickinson, San Jose, CA, USA).

\section{Cell sorting}

BMM cells, obtained as described above, were washed with PBS/3\% FBS and incubated with antibodies $\left(0 \cdot 4 \mu \mathrm{g} / 10^{6}\right.$ cells) against the macrophage marker mouse CD115 and the lymphoid cell markers CD3 and CD45R. CD115 ${ }^{+} \mathrm{CD}^{-}$ $\mathrm{CD}_{45 \mathrm{R}^{-}}{ }^{-}$cells were sorted by flow cytometry in the flow cytometer cell sorter FACSVantage DiVa (BD Biosciences) and seeded in $0.32 \mathrm{~cm}^{2} 96$-well plates at a density of $10^{4} / \mathrm{cm}^{2}$ in $\alpha$-MEM/10\% FBS containing either $100 \mathrm{ng} / \mathrm{ml} \mathrm{M-CSF}$ (controls) or $100 \mathrm{ng} / \mathrm{ml} \mathrm{M-CSF}+50 \mathrm{ng} / \mathrm{ml}$ RANKL, with and without $\mathrm{sCT}\left(10^{-9} \mathrm{M}\right)$. After $4-5$ days, with a change of medium after 3 days, the cultures were harvested and the cells fixed with acetone in citrate buffer $/ 3 \%$ formaldehyde and subsequently stained for TRAP.

\section{TRAP activity assay}

Spleen cells were isolated, as described above, and seeded in $24-w e l l$ plates at a cell density of $10^{6} \mathrm{cells} / \mathrm{cm}^{2}$. The cells were allowed to settle overnight before medium was changed, and then cultured for an additional 4 days (as described above). The cells were then washed in PBS and lysed in Triton X-100 (0.2\% in $\left.\mathrm{H}_{2} \mathrm{O}\right)$. After centrifugation, supernatant was collected and kept at $-20{ }^{\circ} \mathrm{C}$ until analyses. TRAP activity was determined using $p$-nitrophenyl phosphate as substrate at $\mathrm{pH} 4 \cdot 9$, in the presence of tartrate $(0 \cdot 17 \mathrm{M})$ according to the manufacturer's instructions (Sigma). The activity of the enzyme was assessed as the $\mathrm{OD}_{405}$ of liberated $p$-nitrophenol, and normalised to the amount of cell protein analysed using the BCA protein assay kit (Pierce, Rockford, IL, USA). The enzyme assays were performed under conditions where the reaction was proportional to amount of enzyme and reaction time.

\section{cAMP formation}

BMMs were seeded in 24-well plates at a density of $10^{4}$ cells $/ \mathrm{cm}^{2}$ in $\alpha$-MEM/10\% FBS containing either $100 \mathrm{ng} / \mathrm{ml} \mathrm{M-CSF}$ (controls) or $100 \mathrm{ng} / \mathrm{ml} \mathrm{M-CSF}$ $+100 \mathrm{ng} / \mathrm{ml}$ RANKL. After $96 \mathrm{~h}$, cells were washed in serum-free $\alpha$-MEM, and thereafter incubated in HEPESbuffered $\alpha$-MEM containing $10^{-5} \mathrm{M}$ rolipram for $30 \mathrm{~min}$, after which CT $\left(10^{-9} \mathrm{M}\right.$, final concentration) was added. After 2-15 min, cells were harvested and cAMP was extracted from the cells, using 90\% n-propanol. Propanol was removed by evaporation, and the remaining sample was resuspended in assay buffer and analysed using a cAMP $\left[{ }^{125} \mathrm{I}\right]$ RIA Kit, according to the manufacturer's instructions.

\section{Pit formation}

Bone slices with a diameter of $5 \mathrm{~mm}$ and a thickness of $100 \mu \mathrm{m}$ were prepared from bovine femur, washed in ethanol and PBS and then ultrasonicated. The slices were placed at the bottom of 96-well plates, and BMMs (3200 cells/well) were added in $125 \mu \mathrm{l} \alpha$-MEM/10\%FBS with or without test substances. 
After 7 days, the cells were removed with trypsin, ultrasonicated and the bone slices stained with toluidine blue to detect the resorption pits.

\section{Gene expression in spleen cell and BMM cultures}

Spleen cells were isolated, as described above, and seeded in Petri dishes with a growth surface of $20 \mathrm{~cm}^{2}$, at a cell density of $10^{6}$ cells $/ \mathrm{cm}^{2}$. After allowing the cells to settle overnight, medium was changed and the experiment started. Cells were cultured in medium (controls), in medium containing M-CSF $(25 \mathrm{ng} / \mathrm{ml})$ and RANKL $(100 \mathrm{ng} / \mathrm{ml})$, or in complete medium supplemented with M-CSF, RANKL and $\operatorname{sCT}\left(10^{-9} \mathrm{M}\right)$. At $24,48,72$ or $96 \mathrm{~h}$, the cells were collected using a cell scraper and total RNA was extracted.

BMMs were seeded at a density of $10^{4}$ cells $/ \mathrm{cm}^{2}$ in $10 \mathrm{~cm}^{2}$ six-well plates and cultured in $\alpha$-MEM/10\% FBS added to either M-CSF $(100 \mathrm{ng} / \mathrm{ml})$ or M-CSF $(100 \mathrm{ng} / \mathrm{ml})+$ RANKL $(50 \mathrm{ng} / \mathrm{ml})$, in the absence or presence of $\mathrm{sCT}$ $\left(10^{-9} \mathrm{M}\right)$. At 48 and $96 \mathrm{~h}$, total RNA was extracted.

\section{$R N A$ isolation and first-strand $c D N A$ synthesis}

Total RNA was extracted using either TRIzol reagent (Invitrogen) or using the RNAqueous-4PCR kit (Ambion, Cambs, UK) according to the manufacturer's instructions. Then the samples were subsequently digested with DNA-free Kit (Ambion). The quality of the RNA preparations was analysed in $1 \cdot 5 \%$ agarose gel electrophoreses and visualised using ethidium bromide. Single-stranded cDNAs were synthesised from $1 \mu \mathrm{g}$ total RNA using a First-Strand cDNA Synthesis Kit with avian myeloblastosis virus (AMV) and oligo $(\mathrm{dT})_{15}$ primers, according to the manufacturer's protocol (Roche). To ensure that there was no genomic DNA in the samples, reactions without AMV reverse transcriptase were included as a negative control. The mRNA expression was then analysed, using semi-quantitative reverse transcriptase-PCR (RT-PCR) or quantitative real-time PCR.

\section{Semi-quantitative reverse transcriptase-PCR}

First-strand cDNA was amplified by PCR using a PCR core kit (Roche) and PC690G Gradient Thermal Cycler (Corbett Research, Mortlake, NSW, Australia) or Mastercycler Gradient (Eppendorf, Hamburg, Germany). The PCRs for GAPDH, 36B4, TRAP, cathepsin K, chloride channel-7 (ClC-7), c-Fms, c-Jun, c-Fos, TREM-3, DC-STAMP, Atp6v0d1 and ATP6i were performed by PCR standard protocol. The conditions for PCR were: denaturing at $94{ }^{\circ} \mathrm{C}$ for $2 \mathrm{~min}$, annealing at various temperatures for $35 \mathrm{~s}$, followed by elongation at $72{ }^{\circ} \mathrm{C}$ for $40 \mathrm{~s}$; in subsequent cycles denaturing was performed at $94^{\circ} \mathrm{C}$ for $35 \mathrm{~s}$. The PCRs for CTR, TREM-2, NFAT-2, integrin $\alpha_{\mathrm{v}}$, integrin $\beta_{3}$, Atp6v0d2 and matrix metalloproteinase-9 (MMP-9) were initiated with hot start, using HotStar Taq polymerase kit (Qiagen Ltd). Annealing temperatures were $55^{\circ} \mathrm{C}$ (DC-STAMP), $57^{\circ} \mathrm{C}$ (GAPDH, cathepsin K, c-Fms, c-Jun, c-Fos, ClC-7, integrin $\alpha_{\mathrm{v}}$, integrin $\beta_{3}$, MMP-9 and TREM-2), $58^{\circ} \mathrm{C}$ (Atp6v0d1,
Atp6v0d2 and TRAP), $61{ }^{\circ} \mathrm{C}$ (36B4, NFAT-2, TREM-3 and ATP6i) and $67^{\circ} \mathrm{C}$ (CTR). The PCRs for RANK and DAP12 were performed with a step-down technology, where the primer annealing temperature was $65^{\circ} \mathrm{C}$ for the first ten cycles, and then decreased by $5{ }^{\circ} \mathrm{C}$ every five cycles down to $45^{\circ} \mathrm{C}$. The sequences of primers, GenBank accession numbers and the positions for the $5^{\prime}$ - and $3^{\prime}$-ends of the nucleotides for the predicted PCR products are listed in supplementary table 1 (see supplementary data in the online version of the Journal of Endocrinology at http://joe. endocrinology-journals.org/content/vol195/issue3/). The expressions of these factors were compared at the logarithmic phase of the PCR, the products separated in electrophoreses on a $1 \cdot 5 \%$ agarose gel, and visualised using ethidium bromide. Primers were designed using ABI Prism Primer express (Applied Biosystems, Foster City, CA, USA) or Omiga (Genetic Computer Group Inc., Madison, WI, USA). The identity of the PCR products was confirmed using a QIAquick purification kit (Qiagen Ltd) and a Thermo Sequence-TM II DYEnamic ET terminator cycle sequencing kit (Amersham) with sequences analysed on an ABI377 XL DNA sequencer.

\section{Quantitative real-time PCR}

Quantitative real-time PCR analyses of NFAT-2, RANK, TRAP, cathepsin K and CTR were performed by the TaqMan Universal PCR Master Mix (Applied Biosystems) and a sequence detection system (ABI Prism 7900 HT Sequence Detection System and Software, Applied Biosystems) with fluorescence labelled probes (reporter fluorescent dye VIC at the $5^{\prime}$-end and quencher fluorescent dye TAMRA at the $3^{\prime}-$ end) as described previously (Ahlen et al. 2002). The sequences of primers and probes, GenBank accession numbers and the positions for the $5^{\prime}$ - and $3^{\prime}$-ends of the nucleotides for the predicted PCR products are listed in supplementary table 2 (see supplementary data in the online version of the Journal of Endocrinology at http://joe.endocrinology-journals.org/ content/vol195/issue3/). Primers and probes were designed using ABI Prism Primer express (Applied Biosystems). The expressions of c-Fms, ATP6i, integrin $\beta 3$, MMP-9, OSCAR, a disintegrin and metalloproteinase domain 8 (ADAM8) and ADAM12 were analysed using TaqMan Gene Expression assays. To control variability in amplification due to differences in starting mRNA concentrations, $\beta$-actin was used as an internal standard. The relative expression of target mRNA was computed from the target $C_{\mathrm{t}}$ values and the $\beta$-actin $C_{\mathrm{t}}$ value using the standard curve method (User Bulletin no. 2, Applied Biosystems).

\section{Apoptosis}

Spleen cells were seeded in a 96-well plate at a density of $10^{6}$ cells $/ \mathrm{cm}^{2}$. The cells were allowed to settle overnight in the complete medium after which the medium was changed to medium containing $25 \mathrm{ng} / \mathrm{ml} \mathrm{M-CSF}$ and $100 \mathrm{ng} / \mathrm{ml}$ RANKL. At $72 \mathrm{~h}$, sCT $\left(10^{-9} \mathrm{M}\right)$ was added to the cultures, which were then incubated for 4 or $14 \mathrm{~h}$ before harvest. 
Cultures without CT were used as a control. Cells were washed in PBS and lysed. DNA fragmentation was then analysed using Cell Death Detection ELISA (Roche).

\section{Statistical analyses}

All statistical analyses were performed by one-way ANOVA with Levene's homogenicity test, and post hoc Bonferroni's test, or where appropriate, Dunnett's T3 test or using the independent sample $t$-test (SPSS for Windows, Apache Software Foundation). All experiments have been performed at least twice with comparable results, and all data are presented as means \pm s.E.M.

\section{Results}

Effects of CT on osteoclast formation in spleen cell cultures

Treatment of mouse spleen cells with M-CSF (25 ng/ml) and RANKL $(100 \mathrm{ng} / \mathrm{ml})$ resulted in an increased number of TRAP $^{+}-\mathrm{MuOCL}$, which was evident after $72 \mathrm{~h}$ and maximal after $96 \mathrm{~h}$, after which time point the number declined (Fig. 1A). The addition of sCT $\left(10^{-9} \mathrm{M}\right)$ to spleen cells stimulated by M-CSF and RANKL resulted in $70 \%$ inhibition of the number of osteoclasts formed at $96 \mathrm{~h}$
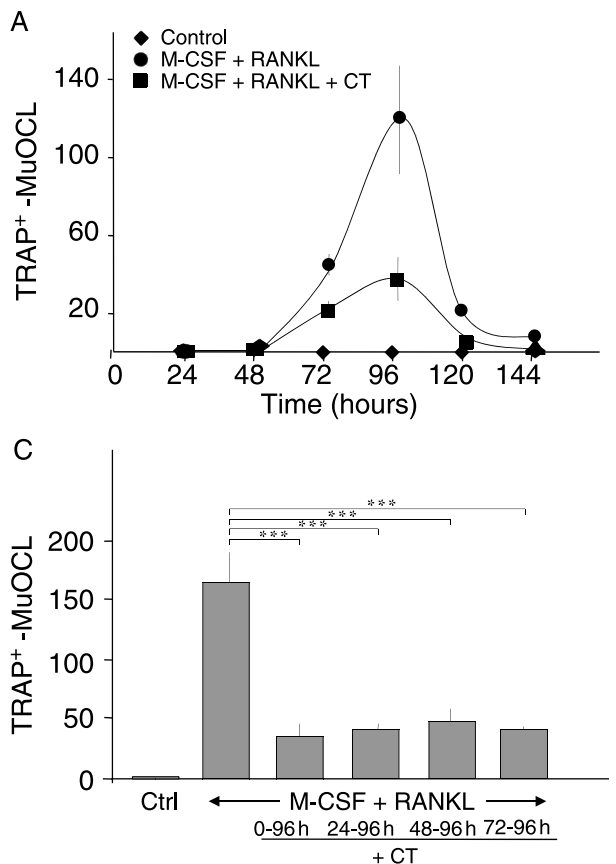

Figure 1 The inhibitory effect of $\mathrm{sCT}$ on osteoclast $\left(\mathrm{TRAP}^{+}-\mathrm{MuOCL}\right)$ formation in spleen cell cultures stimulated by M-CSF and RANKL is dependent on time (A) and concentration (B) and can be obtained by adding calcitonin during the last 72,48 or $24 \mathrm{~h}$ of a 96-h culture (C). The expression of the CTR was upregulated by RANKL but was inhibited by the addition of calcitonin, as assessed by quantitative real-time PCR (D). sCT was added to a final concentration of $10^{-9} \mathrm{M}$ in (A), (C) and (D). Symbols and columns represent the mean of six wells per group and S.E.M. is given as vertical bars when larger than the height of the symbol. ${ }^{* * *}$ Statistical significance at $P<0 \cdot 001$.
(Fig. 1A). The inhibitory effect of $\mathrm{sCT}$ was concentration dependent $\left(10^{-14}-10^{-9} \mathrm{M}\right)$ with apparent half maximal inhibition obtained at $10^{-12} \mathrm{M}$ (Fig. 1B). The degree of inhibition caused by adding sCT during the last $24 \mathrm{~h}$ of a $96-\mathrm{h}$ culture was identical to that obtained when $\mathrm{sCT}$ was present during the complete culture period (Fig. 1C). Treatment with $\mathrm{M}-\mathrm{CSF}$ and RANKL induced a time-dependent enhanced expression of CTR mRNA, a response which was abolished by $\mathrm{sCT}$ (Fig. 1D).

\section{Expression of c-Fms and RANK $m R N A$ in CT-treated cells}

When assessed at $96 \mathrm{~h}$ by semi-quantitative RT-PCR, it was observed that M-CSF and RANKL stimulation of spleen cells caused a substantial increase of both c-Fms and RANK mRNA, which was unaffected by sCT (Fig. 2A). To study whether sCT treatment had affected the c-Fms and RANK mRNA expressions during earlier stages of osteoclast progenitor cell differentiation, the c-Fms and RANK mRNA expressions were analysed using quantitative realtime PCR at 24-96 h. As shown in Fig. 2B, the c-Fms mRNA expression was enhanced by treatment of the spleen cells with M-CSF and RANKL for $72 \mathrm{~h}$, but sCT did not affect c-Fms mRNA level at any time point. Similarly, the RANK mRNA expression was unaffected by sCT at all time points (Fig. 2C).
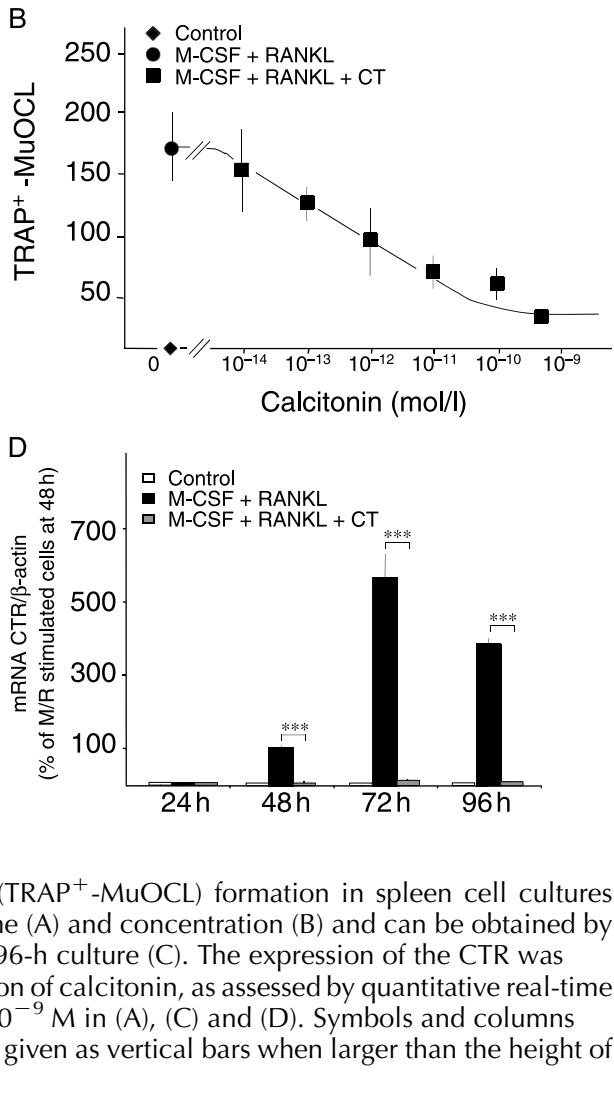
A

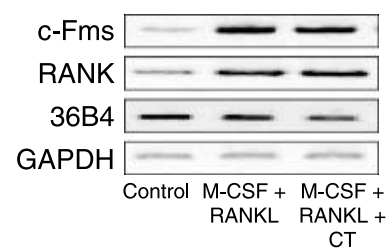

D
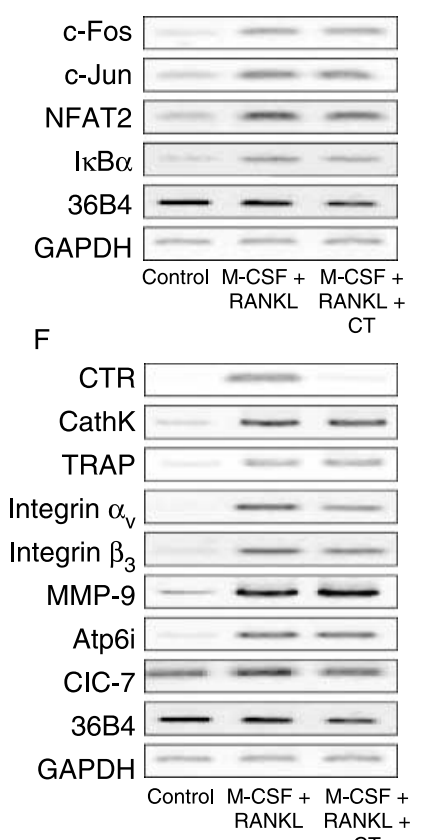

B

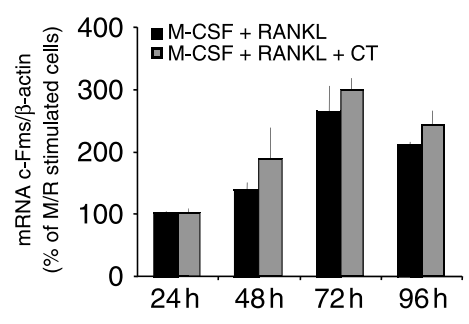

C

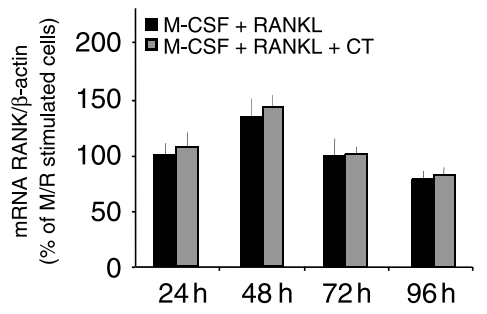

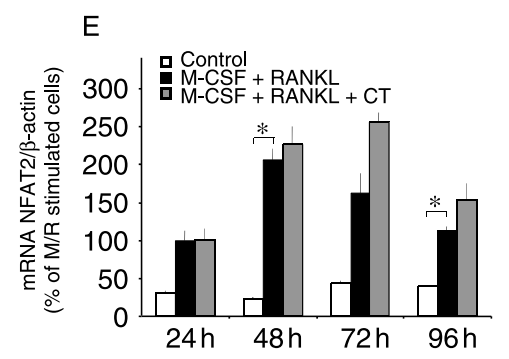

G

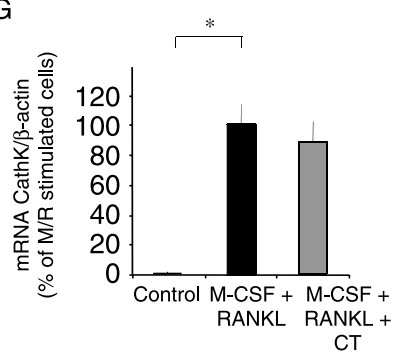

$\mathrm{H}$

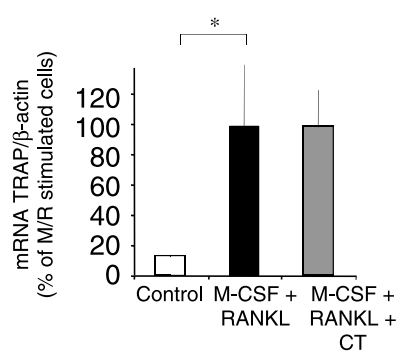

Figure 2 Analysis of mRNA expression in spleen cell cultures. PCR analyses were performed in untreated cells (control) and in cells stimulated with M-CSF and RANKL, with or without $\mathrm{SCT}\left(10^{-9} \mathrm{M}\right)$. Semi-quantitative RT-PCR analyses of mRNA expression of the receptors c-Fms and RANK at $96 \mathrm{~h}$ are shown in (A). In (B and C), the quantitative real-time PCR analyses of c-Fms (B) and RANK (C) at 24-96 h are shown. In (D), the semi-quantitative RT-PCR analyses of the mRNA expression of the transcription factors c-Fos, c-Jun, NFAT-2 and the mRNA expression of $I \kappa B \alpha$, the inhibitory component of the transcription factor $N F-\kappa B$, at $96 \mathrm{~h}$ are shown. In (E), the quantitative real-time PCR analysis of NFAT-2 for 24-96 $\mathrm{h}$ is shown. In (F), the semi-quantitative RT-PCR analyses of the mRNA expression of calcitonin receptor (CTR) and seven genes important for osteoclast function (cathepsin K, TRAP, MMP-9, the proton pump subunit ATP6i, ClC-7 and integrins $\alpha_{v}$ and $\left.\beta_{3}\right)$, cultured for $96 \mathrm{~h}$ are shown. In $(\mathrm{G}$ and $\mathrm{H})$, the quantitative real-time PCR analysis of cathepsin $\mathrm{K}(\mathrm{G})$ and TRAP $(\mathrm{H})$ at $96 \mathrm{~h}$ is shown. In semi-quantitative RT-PCR analyses, the expressions were compared with the two house-keeping genes, 36B4 and GAPDH. Columns represent the mean of four wells and S.E.M. is shown as vertical bars. ${ }^{*}$ Statistical significance at $P<0 \cdot 05$.

Expression of transcription factors involved in osteoclast differentiation in the absence and presence of CT

Stimulation of spleen cells for $96 \mathrm{~h}$ with M-CSF and RANKL caused increased mRNA expression of c-Fos, c-Jun and NFAT-2, as assessed by semi-quantitative RT-PCR (Fig. 2D). As a consequence of NF- $\kappa \mathrm{B}$ activation caused by RANKL-, M-CSF/RANKL-stimulated spleen cells expressed increased mRNA for inhibitory $\kappa \mathrm{B} \alpha$ (I $\kappa \mathrm{B} \alpha$; Fig. 2D) M-CSF/ RANKL-induced increase of mRNA for c-Fos, c-Jun, NFAT-2 and I $\kappa \mathrm{B} \alpha$ was unaffected by sCT (Fig. 2D). sCTinsensitive stimulation of NFAT-2 mRNA by M-CSF/ RANKL treatment was also documented at $24-96 \mathrm{~h}$ by quantitative real-time PCR (Fig. 2E).
Effects of CT on the $m R N A$ expression of genes known to be expressed in terminally differentiated osteoclasts

Treatment of spleen cells with M-CSF and RANKL for $96 \mathrm{~h}$ resulted in increased mRNA expression of CTR, TRAP, cathepsin K, MMP-9, ATP6i and the integrins $\alpha_{\mathrm{v}}$ and $\beta_{3}$, but not of ClC-7, as assessed by semi-quantitative RT-PCR and using either GAPDH or 36B4 as house-keeping genes (Fig. 2F). The addition of sCT $\left(10^{-9} \mathrm{M}\right)$ abolished the M-CSF/RANKL induction of the CTR gene, but did not affect the mRNA expression of any of the other seven osteoclastic genes at the end of the 96-h cultures (Fig. 2F). Using quantitative real-time PCR, it was confirmed that sCT did not affect the enhanced mRNA expression of TRAP and 
cathepsin $\mathrm{K}$ (Fig. 2G and $\mathrm{H}$ ). The enhanced mRNA expression of cathepsin $\mathrm{K}$ and TRAP was observed already after 24-h treatment with M-CSF/RANKL and CT did not affect the mRNA expression at any time point (24-96 h; data not shown).

Effects of CT on the number of TRAP ${ }^{+}$mononucleated cells

The decreased number of $\mathrm{TRAP}^{+}-\mathrm{MuOCL}$ in M-CSF/RANKL-stimulated spleen cell cultures treated with sCT $\left(10^{-9} \mathrm{M}\right)$ was not associated with any decrease of total TRAP activity induced by the M-CSF/RANKL treatment (Fig. 3A). In agreement with the biochemical analysis of TRAP activity, morphological assessment of TRAP-stained spleen cell cultures showed the presence of large numbers of $\mathrm{TRAP}^{+}$, mononucleated cells in the sCT-treated cultures stimulated by M-CSF/RANKL (Fig. 3B and 3C).

\section{Effects of CTon apoptosis}

Using a one-step sandwich ELISA kit, recognizing fragmented DNA bound to histones, we were unable to detect any effect of $\operatorname{sCT}\left(10^{-9} \mathrm{M}\right)$ on apoptosis after $4 \mathrm{~h}$ of treatment (M-CSF+RANKL $100 \pm 13 \%, \mathrm{M}-\mathrm{CSF}+\mathrm{RANKL}+\mathrm{sCT}$ $98 \pm 13 \%$; $\mathrm{OD}_{405} /$ well $)$. Nor did we observe any effect after $14 \mathrm{~h}$ of sCT treatment (M-CSF+RANKL $100 \pm 27 \%$, $\mathrm{M}-\mathrm{CSF}+\mathrm{RANKL}+\mathrm{sCT} 109 \pm 29 \%)$.

Expression of $F C R \gamma, D A P 12$ and associated immunoglobulinlike receptors in the absence and presence of $C T$

Using semi-quantitative RT-PCR, we found that stimulation of spleen cells for $96 \mathrm{~h}$ with M-CSF $(25 \mathrm{ng} / \mathrm{ml})$ and RANKL
$(100 \mathrm{ng} / \mathrm{ml}))$ resulted in increased mRNA expressions of OSCAR at 48-96 h and of NKG2D at 72 and $96 \mathrm{~h}$, whereas the mRNA expressions of DAP12, FCR $\gamma$, TREM-2, TREM-3, SIRP $\beta 1$ and PIR-A6 were unaffected at all time points (supplementary figure; see supplementary data in the online version of the Journal of Endocrinology at http://joe.endocrinology-journals.org/content/vol195/issue3/). The addition of sCT $\left(10^{-9} \mathrm{M}\right)$ to the M-CSF/RANKL-stimulated spleen cells did not affect the mRNA expressions of DAP12 or FcR $\gamma$, nor the receptors to which these ITAM harbouring molecules dimerise (supplementary figure; see supplementary data in the online version of the Journal of Endocrinology at http://joe. endocrinology-journals.org/content/vol195/issue3/).

\section{Effect of CT on osteoclast formation, pit formation and gene} expression in BMMs

It has been shown that T-cell-derived cytokines such as granulocyte-M-CSF, interferon- $\gamma$, interleukin-4 (IL-4) and IL-13 can negatively influence osteoclast progenitor cell differentiation (Takayanagi et al. 2000, Moreno et al. 2003, Shinoda et al. 2003), and that T-cells are required for the inhibitory effects of IL-12 and IL-18 (Horwood et al. 1998, 2001). We, therefore, studied whether CT had any effect on osteoclastogenesis in a population of BMM, highly enriched for osteoclast progenitor cells, obtained by culturing mouse bone marrow cells in the presence of M-CSF for 6 days on plastic dishes, to which neither T- and B-cells, nor stromal cells, can adhere. The BMM cells used were devoid of T- and B-cells as indicated by the lack of cells expressing CD45R and CD3, as assessed by FACS analysis (Fig. 4A). CD115/c-Fms was expressed on $75 \%$ of the cells and all cells expressed the macrophage marker CD11b/Mac-1. As a comparison, crude

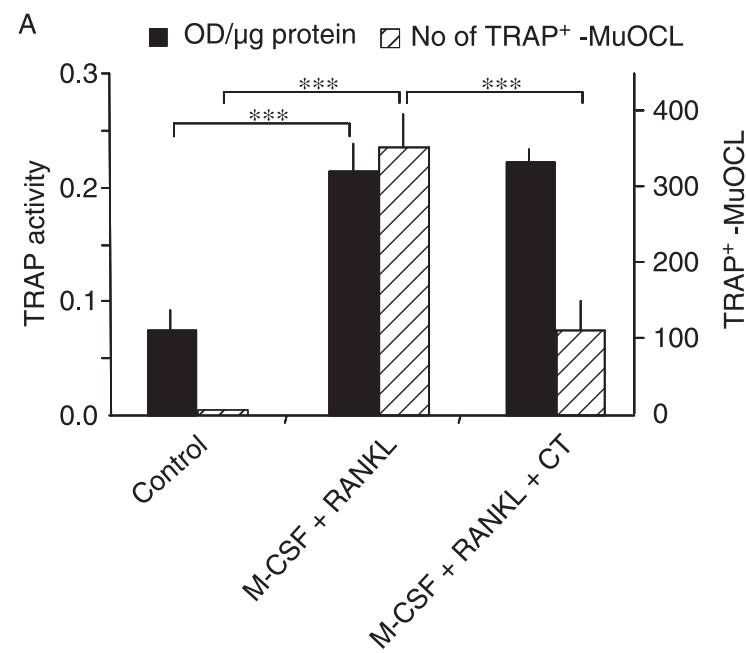

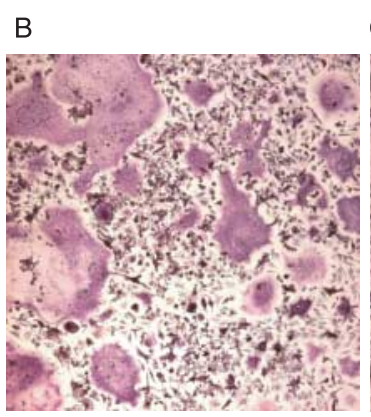

M-CSF + RANKL
C

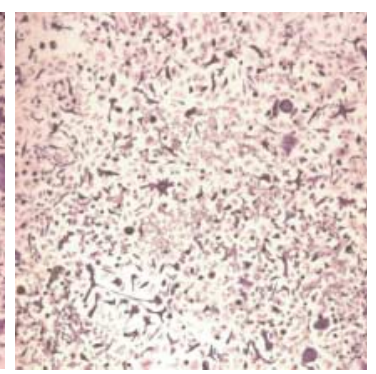

$\mathrm{M}-\mathrm{CSF}+\mathrm{RANKL}$ $+\mathrm{CT}$

Figure 3 The number of TRAP $^{+}{ }_{-} \mathrm{MuOCL}$ was counted and in parallel cultures TRAP activity was quantified. Treatment with sCT $\left(10^{-9} \mathrm{M}\right)$ results in decreased amounts of $\mathrm{TRAP}^{+}$multinucleated osteoclasts associated with unchanged levels of total TRAP activity (A). TRAP staining of spleen cells cultured for $96 \mathrm{~h}$ in medium containing M-CSF and RANKL (B) and in medium containing M-CSF, RANKL and calcitonin (C). Decreased number of TRAP ${ }^{+}-M u O C L$ was associated with a large number of $\mathrm{TRAP}^{+}$mononuclear osteoclast progenitor cells (C). ${ }^{* * *}$ Statistical significance at $P<0 \cdot 001$. 
bone marrow cells contain CD3, CD45R and CD11b-positive cells, but almost completely lack CD115-positive cells (Fig. 4A). As appears in Fig. 4B, sCT inhibited M-CSF/RANKL-induced formation of $\mathrm{TRAP}^{+}{ }_{-} \mathrm{MuOCL}$ in the BMM cultures to a degree comparable with the inhibition seen in spleen cells (Fig. 1B), with half maximal inhibition at $10^{-12} \mathrm{M}$. hCT also concentration dependently inhibited formation of TRAP ${ }^{+}$ $\mathrm{MuOCL}$, but was considerable less potent than sCT (Fig. 4B). Similarly, TRAP $^{+}$-MuOCL formation in a population of initially non-adherent BMMs (Roach et al. 1997) stimulated by M-CSF and RANKL was reduced by $80 \%$ by sCT $\left(10^{-9} \mathrm{M}\right.$; data not shown). The addition of sCT to BMM stimulated by $\mathrm{M}-\mathrm{CSF}$ and RANKL resulted in a large number of TRAP ${ }^{+}$ mononucleated cells (Fig. 4C). The number of resorption pits on devitalised bone slices was abolished by treatment of BMM with sCT (Fig. 4D). The number of $\mathrm{TRAP}^{+}{ }_{-\mathrm{MuOCL}}$ seen was clearly decreased by $\mathrm{CT}$ when culturing $\mathrm{CD} 115^{+} \mathrm{CD} 3^{-}$
$\mathrm{CD} 45 \mathrm{R}^{-}$sorted BMM with M-CSF and RANKL in combination with CT (Fig. 4E). Also in these cultures, the inhibitory effect of CTon osteoclastogenesis was associated with the appearance of $\mathrm{TRAP}^{+}$mononucleated cells.

Semi-quantitative RT-PCR revealed that RANKL induced an increase in mRNA expression of OSCAR, DC-STAMP but not of DAP12 and FcR $\gamma$ in BMM cells at $96 \mathrm{~h}$ (Fig. 5A). Similar to the observation in spleen cells, sCT did not affect the mRNA expressions of DAP12, FcR $\gamma$ or OSCAR in BMM. Neither was DC-STAMP expression affected by sCT (Fig. 5A). Quantitative real-time PCR showed that CTR, cathepsin K, TRAP, ATP6i, integrin $\beta_{3}$, MMP-9 and OSCAR mRNA were increased by RANKL (Fig. 5B-H). The inhibition of osteoclastogenesis caused by SCT in the adherent BMM was associated with decreased mRNA expression of CTR (Fig. 5B), with no effect on the mRNA expressions of the other genes assessed (Fig. $5 \mathrm{C}-\mathrm{H}$ ).
A $\mathrm{BMC}$

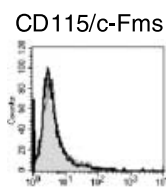

BMM
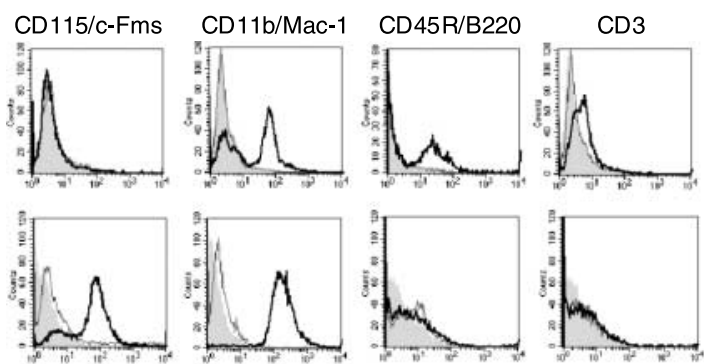

Unstained cells

s - Isotype control

- Specific binding

B

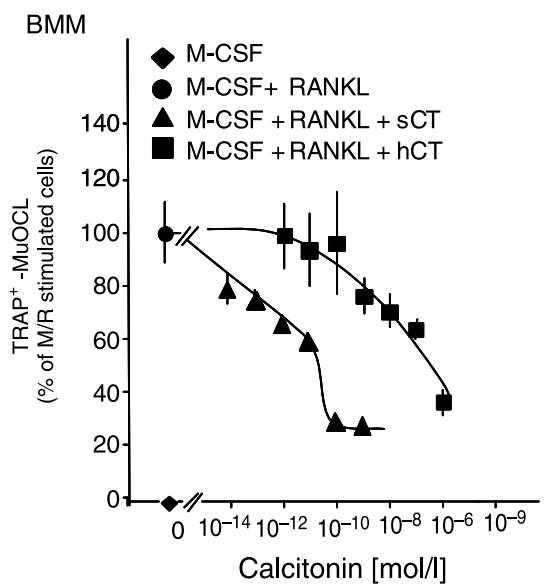

C

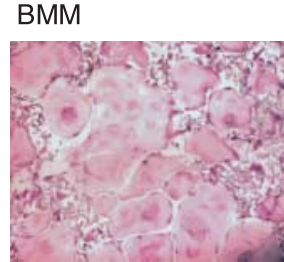

$M-C S F+R A N K L$

BMM

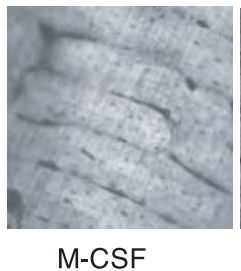

$E$

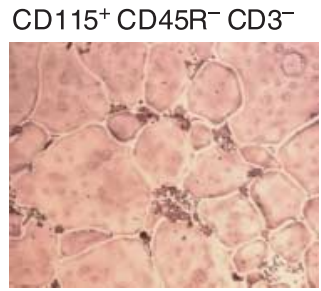

$\mathrm{M}-\mathrm{CSF}+\mathrm{RANKL}$

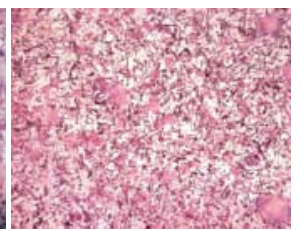

$\mathrm{M}-\mathrm{CSF}+\mathrm{RANKL}+\mathrm{CT}$

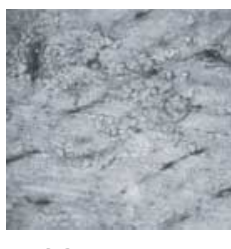

$\mathrm{M}-\mathrm{CSF}+\mathrm{RANKL} \quad \mathrm{M}-\mathrm{CSF}+\mathrm{RANKL}$ $+\mathrm{CT}$

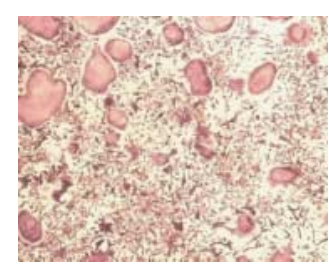

$M-C S F+R A N K L+C T$

Figure 4 Flow cytometry analysis of bone marrow cells (BMCs) reveals that there is a population of cells which express CD11b and CD45R and that some cells express CD3, whereas no cells that express CD115 can be detected (A). In bone marrow macrophage (BMM) cultures, all cells are positive for CD11b and $\sim 75 \%$ express CD115 on their cell surface. No cells that express CD45R or CD3 can be detected in these BMM cultures (A). Salmon and human calcitonin inhibit the formation of osteoclasts in bone marrow macrophage cultures, stimulated by M-CSF and RANKL for $96 \mathrm{~h}$, in a concentration-dependent manner (B). TRAP staining shows multinucleated TRAP ${ }^{+}$cells in BMM cultures stimulated by M-CSF and RANKL (C, left) and mononucleated TRAP ${ }^{+}$cells in cultures treated with calcitonin ( $\mathrm{C}$, right). Calcitonin inhibits bone resorption by BMM cells stimulated with M-CSF and RANKL (D, right) compared with cultures without calcitonin (D, centre). TRAP staining shows that M-CSF and RANKL induce formation of multinucleated TRAP ${ }^{+}$cells in $\mathrm{CD}_{115}{ }^{+} \mathrm{CD}^{-} \mathrm{CD} 45 \mathrm{R}^{-}$sorted BMM cultures (E, left) and that calcitonin inhibits the multinucleation process in these cultures (E, right). 
A

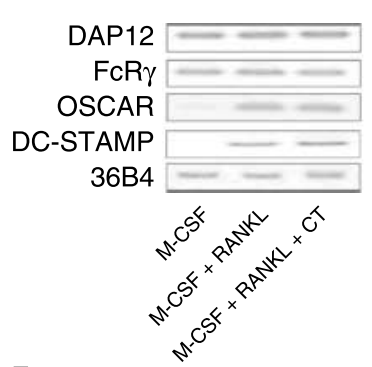

$\mathrm{E}$

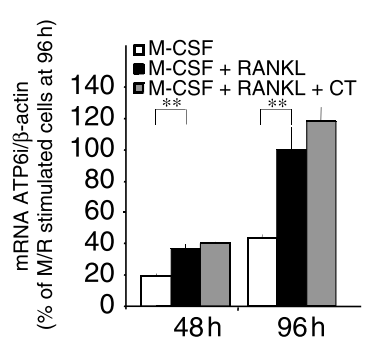

B

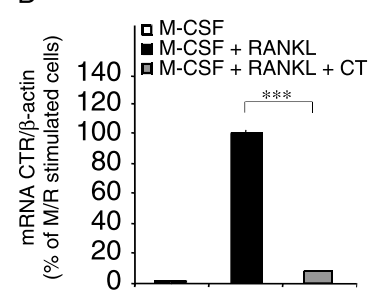

C

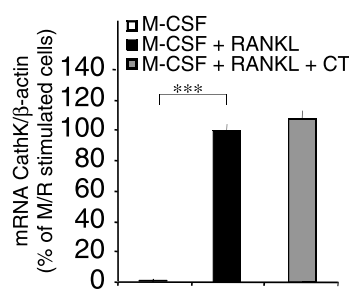

D

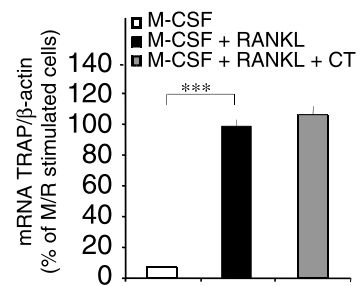

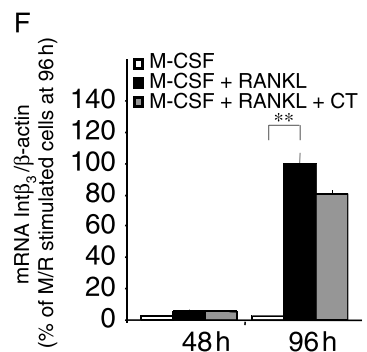
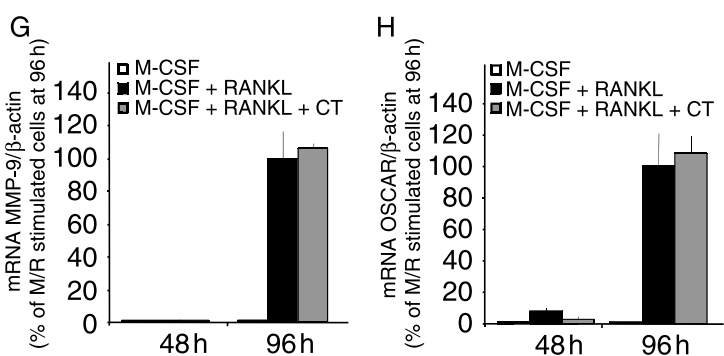

Figure $5 \mathrm{sCT}\left(10^{-9} \mathrm{M}\right)$ does not affect the mRNA expression of DAP12, FcR $\gamma$, OSCAR and DC-STAMP in M-CSF/RANKL-stimulated BMM cells at $96 \mathrm{~h}$, as assessed by semi-quantitative RT-PCR (A). In M-CSF/RANKL-stimulated BMM cells, sCT (10 $\left.{ }^{-9} \mathrm{M}\right)$ inhibits the mRNA expression of CTR, without affecting the increased mRNA expressions of cathepsin K, TRAP, ATP6i, integrin $\beta_{3}$, MMP-9 and OSCAR, as assessed by quantitative real-time PCR $(\mathrm{B}-\mathrm{H})$. The expressions of cathepsin $\mathrm{K}$ and TRAP were analysed at $96 \mathrm{~h}$ and the expressions of ATP6i, integrin $\beta 3$, MMP-9 and OSCAR were analysed at 48 and $96 \mathrm{~h}$. Columns represent the mean of four wells and s.E.M. is shown as vertical bars. **Statistical significance at $P<0 \cdot 01,{ }^{* * *}$ statistical significance at $P<0 \cdot 001$.

CT did not affect Atp6v0d2 or Atp6v0d1 mRNA expression in M-CSF/RANKL-stimulated BMM at 48 or $96 \mathrm{~h}$ (data not shown). It was suggested by Lee et al. (2006) that ADAM8 and ADAM12 were partially involved in the mechanism downstream Atp6v0d2. However, quantitative real-time PCR analysis showed that CT did not affect ADAM8 or ADAM12 mRNA expression at 48 and $96 \mathrm{~h}$ in M-CSF/RANKL-stimulated BMM (data not shown).

\section{Effects of cAMP analogues on osteoclast formation}

The addition of CT to BMM cultures stimulated by M-CSF/RANKL caused a time-dependent accumulation of cAMP (Fig. 6A), which was not seen in BMM cultures stimulated with only M-CSF (Fig. 6B), in agreement with the mRNA data (Fig. 5B). Forskolin is a well-known activator of adenylate cyclase, causing enhanced intracellular accumulation of cAMP. Adding forskolin to BMM cultures stimulated with M-CSF/RANKL, mimicked the effect of $\mathrm{CT}$, resulting in decreased number of $\mathrm{TRAP}^{+}{ }^{-} \mathrm{MuOCL}$ with very many $\mathrm{TRAP}^{+}$mononucleated cells being observed (Fig. 6C and D). Since cAMP functions as a second messenger activating at least two pathways, the PKA signalling and the Epac signalling (Kawasaki et al. 1998, de Rooij et al. 1998), we examined the effect of two different cAMP analogues; 6-MB-cAMP, which activates PKA but not Epac, and 8-pMeOPT-2'-o-cAMP which activates Epac but does not affect PKA. Both analogues caused an inhibition of the number of $\mathrm{TRAP}^{+}{ }_{-\mathrm{MuOCL}}$ with very many $\mathrm{TRAP}^{+}$ mononucleated cells, similar to the findings in cultures treated with CT (Fig. 6C and D). On the contrary, 8-bromo$5^{\prime}$-AMP, a cAMP analogue which cannot activate either PKA or Epac signalling, showed no effect on the number of TRAP $^{+}$-MuOCL formed (Fig. 6C and E).

\section{Discussion}

In the present study, we show that $\mathrm{sCT}$ and hCT inhibit osteoclast formation in mouse spleen and mouse BMM cell cultures, with half maximal inhibition at $10^{-12} \mathrm{M}$ for sCT and hCT being considerably less potent, in agreement with its lower affinity to the mouse CTR. This observation is in agreement with a study by Cornish et al. (2001) in which rat CT was used, which to the best of our knowledge, is the only previous report demonstrating a concentration-dependent inhibitory effect by CTon osteoclastogenesis. In the studies by Cornish et al. (2001), mouse bone marrow cultures stimulated by $\mathrm{D}_{3}$ were used to study osteoclast formation and the possibility therefore may exist that CT could have exerted its effect not directly on osteoclast progenitor cells, but indirectly via contaminating cells present in the crude bone marrow cultures. This possibility could also hold true in our spleen cell cultures. Even though it could be argued that such a possibility is unlikely, given the fact that CTR expression is a highly specific expression of osteoclasts, it should not be ignored that CTR has also been shown to be present in other cell types including lymphocytes (Body et al. 1994). 
A

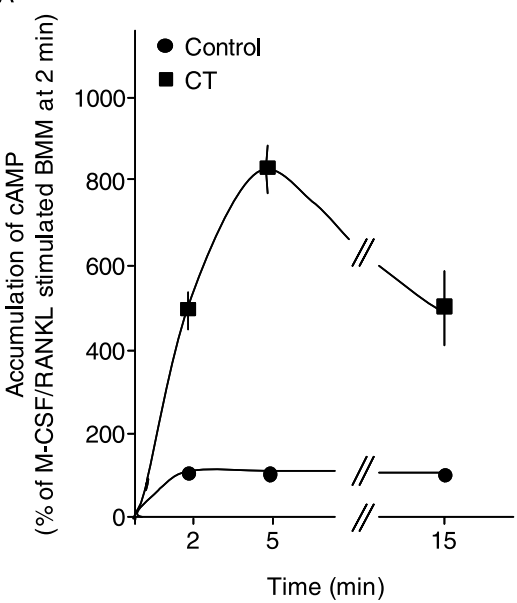

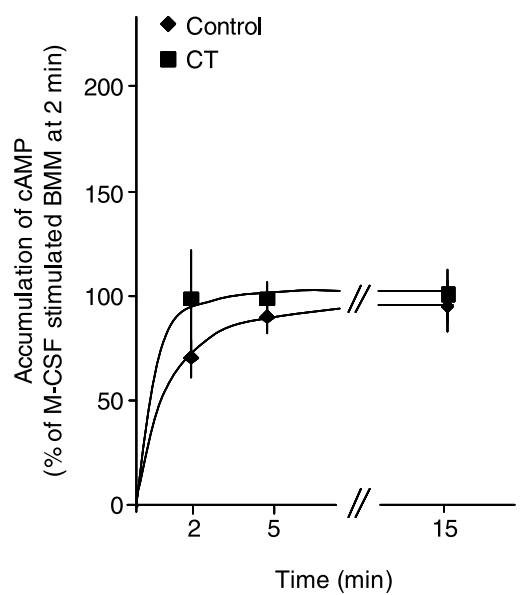

C
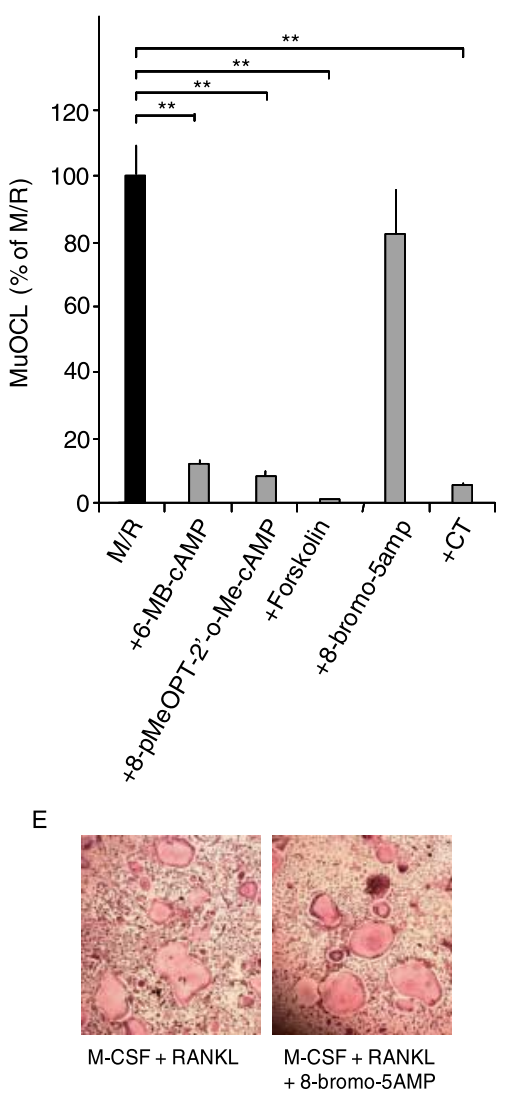

Figure 6 Addition of $\mathrm{SCT}\left(10^{-9} \mathrm{M}\right)$ to BMM cultures stimulated by M-CSF/RANKL caused an accumulation of cAMP (A). In BMM cultures stimulated by M-CSF alone, sCT did not affect the cAMP levels (B). Forskolin $(10 \mu \mathrm{M}), 6-\mathrm{MB}$-cAMP $(50 \mu \mathrm{M})$ and 8-pMeOPT-2'-o-Me-cAMP $(50 \mu \mathrm{M})$, inhibit the formation of TRAP ${ }^{+}-\mathrm{MuOCL}$ in M-CSF/RANKL-stimulated BMM cultures, similar to the effect caused by $\mathrm{SCT}\left(10^{-9} \mathrm{M}^{-} \mathrm{C}_{-}\right.$ D). 8-bromo-5'-AMP $(100 \mu M)$ did not affect the formation of osteoclasts ( $\mathrm{C}$ and E). Symbols and columns represent the mean of four wells and S.E.M. is shown as vertical bars. $* *$ Statistical significance at $P<0 \cdot 01$. Data in (A) are based on two separate experiments, where the numbers of osteoclasts in M-CSF/RANKL-stimulated cultures were 157 \pm 13/well and 219 $\pm 22 /$ well respectively.

We, therefore, used BMM highly enriched in osteoclast precursor cells, as well as BMM cells positively sorted for CD115 and negatively for CD45R and CD3, and could show that CT inhibits osteoclast formation stimulated by M-CSF/ RANKL also in these cells. These findings strongly suggest that the inhibitory effect of CT on osteoclastogenesis is due to an effect directly on osteoclast progenitor cells. The inhibitory effect of CT was obtained by adding CT during the last 24 of the $96-\mathrm{h}$ cultures.

We assessed the possibility that CT-induced inhibition of osteoclastogenesis was due to increased apoptosis of osteoclast progenitor cells by an ELISA kit, recognizing fragmented DNA bound to histones. However, CT did not increase the intracellular levels of fragmented DNA.

Having established that CT inhibits osteoclastogenesis, our next aim was to determine the mechanism by which activation of CTR interferes with the downstream signalling events involved in RANK activation of osteoclast formation. First of all, we could exclude that CT affected the mRNA expression of the receptors for RANKL and M-CSF. The knowledge about intracellular signalling mechanisms involved in osteoclast progenitor cell differentiation is still emerging. However, CT did not affect the increased mRNA expression of I $\mathrm{B} \mathrm{B} \alpha$, c-Fos, c-Jun or NFAT-2 caused by RANK. In addition, we assessed the mRNA expression of a wide variety of genes known to be important for osteoclast function (Teitelbaum \& Ross 2003). However, CT did not affect RANK-induced increased mRNA expression of TRAP, cathepsin K, MMP-9, the proton pump subunit ATP6i, ClC7 or the integrins $\alpha_{\mathrm{v}}$ and $\beta_{3}$. These observations indicate that $\mathrm{CT}$ inhibits osteoclast formation at a very late stage, a view compatible with the observation that addition of CT during the last $24 \mathrm{~h}$ was sufficient to cause the inhibitory effect. The view is also in line with the observation that a large number of $\mathrm{TRAP}^{+}$mononucleated cells was present in CT-treated M-CSF/RANKL-stimulated spleen cells and BMM, as well as with the fact that $\mathrm{CT}$ did not affect the increase of total TRAP activity caused by M-CSF/RANKL treatment. 
DAP12, FcR $\gamma$ and the immunoglobulin-like receptors to which these transmembrane signalling molecules are bound, have been suggested to be important at late stages of osteoclastogenesis, possibly at the fusion process (Paloneva et al. 2003). Taken together, our findings indicate that CT may play a role in osteoclast formation during the multinucleation process. We, therefore, analysed whether CT affected the mRNA expressions of DAP12 and FcR $\gamma$, and the receptors associated with them. We found that stimulation of osteoclast formation in spleen cell cultures with M-CSF/ RANKL was associated with increased mRNA expression of OSCAR, both at early and late stages of osteoclast differentiation. We also found that the mRNA expression of NKG2D was enhanced during later stages of osteoclastogenesis. However, the mRNA expressions of TREM-2, TREM3 and SIRP $\beta 1$, as well as the mRNA expression of PIR-A6 were unregulated both at early and late stages of osteoclastogenesis. Although the importance of FcR $\gamma$ and DAP12 in osteoclastogenesis has been elegantly demonstrated, there are only very few studies reporting on the regulation of the expression of $\mathrm{FcR} \gamma, \mathrm{DAP} 12$ and the associated receptors. In agreement with the present study, it has been shown that the expressions of OSCAR (Kim et al. 2002, So et al. 2003) and NKG2D (Humphrey et al. 2004) are enhanced by RANKL. However, in contrast to observations in RANKL-stimulated BMM (Humphrey et al. 2004), we were unable to observe any regulation of TREM-2 and TREM-3 in RANKL-stimulated spleen cells. Similar to the observations in the present study, DAP12 mRNA was unregulated by RANKL in BMM (Humphrey et al. 2004). Interestingly, CT did not affect the mRNA expressions of FcR $\gamma$, DAP12 or the associated receptors OSCAR, PIR-A6, TREM-2, TREM-3, NKG2D or SIRP $\beta 1$, neither at early stages of osteoclast formation nor at later stages in M-CSF/RANKL-stimulated spleen cell cultures.

DC-STAMP is a seven-transmembrane-region receptor, upregulated during osteoclast differentiation, which has been shown to be required for fusion of osteoclast progenitor cells (Yagi et al. 2006). Our results confirm the upregulation of DC-STAMP mRNA during osteoclastogenesis, but the enhanced DC-STAMP expression was not affected by CT. Most recently, ATP6v0d2 has been suggested to be crucial for osteoclast multinucleation (Lee et al. 2006). However, the mRNA expression of ATP6v0d2, or the downstream signalling effectors ADAM8 and ADAM12, was not affected by CT.

It is well documented that activation of CTR leads to stimulation of adenylate cyclase and formation of cAMP. The importance of the adenylate cyclase-activating pathway for the effect of CT in osteoclast formation was indicated by the finding that forskolin clearly mimicked the effect of CT. The downstream events of cAMP formation involve activation of the canonical PKA pathway but for some mechanisms also a non-canonical pathway mediated by Epac, a cAMP-regulated guanine nucleotide exchange factor. The latter pathway promotes exchange of GDP for GTP at the guanyl nucleotide-binding site on the small G-protein Rap1 (Kawasaki et al. 1998, de Rooij et al. 1998). Active GTP-binding Rap1 interacts with Raf which can activate a MEK-ERK kinase cascade. The fact that a cAMP analogue which preferentially activates PKA mimicked the effect of CT indicates that the cAMP-PKA pathway is important. Most interestingly, however, a cAMP analogue preferentially activating Epac mimicked the effect of CT, suggesting that the noncanonical pathway is also important. It has been shown that CT rapidly and transiently can stimulate the phosphorylation of ERK1/2 in CTR-expressing cells (Chen et al. 1998, Zhang et al. 2002). This effect was paralleled by activation of protein kinase $C$ and a rise of intracellular calcium, but the elevation of intracellular calcium was not sufficient to fully explain the phosphorylation of ERK1/2, which indicates that other mechanisms contribute. In kidney cells (Laroche-Joubert et al. 2002), it has recently been shown that Epac is important for ERK1/2 activation and therefore, our findings point, for the first time, that not only the PKA but also the Epac-ERK1/2 pathway is involved in the action of osteoclasts.

Our data show that CT is a potent inhibitor of osteoclast formation and that this effect is not associated with apoptosis, nor decreased transcription of a variety of genes known to be important for osteoclast progenitor cell differentiation, fusion or function. These data show that inhibition of bone resorption in vivo by $\mathrm{CT}$ may be explained not only by an acute effect on multinucleated osteoclast formation but also by an effect on osteoclast formation.

Elucidating the molecular mechanism by which CT inhibits osteoclastogenesis could be helpful in finding a novel target for the development of new inhibitors of bone resorption.

\section{Acknowledgements}

This project was supported by grants from the Swedish Science Council (project no. 07525), the Swedish Rheumatism Association, the Royal 80 Year Fund of King Gustav V, SalusAnsvar and the County Council of Västerbotten. We are grateful for the excellent technical support by Mrs Anita Lie and Mrs Inger Lundgren. The authors declare that there is no conflict of interest that would prejudice the impartiality of this scientific work.

\section{References}

Ahlen J, Andersson S, Mukohyama H, Roth C, Bäckman A, Conaway HH \& Lerner UH 2002 Characterization of the bone resorptive effect of interleukin-11 in cultured mouse calvarial bones. Bone 31 242-251.

Asagiri M \& Takayanagi H 2007 The molecular understanding of osteoclast differentiation. Bone 40 251-264.

Body JJ, Fernandez G, Lacroix M, Vandenbussche P \& Content J 1994 Regulation of lymphocyte calcitonin receptors by interleukin-1 and interleukin-6. Calcified Tissue International 55 109-113.

Boyle WJ, Simonet WS \& Lacey DL 2003 Osteoclast differentiation and activation. Nature 423 337-342.

Chambers TJ, Athanasou NA \& Fuller K 1984 Effect of parathyroid hormone and calcitonin on the cytoplasmatic spreading of rat osteoclasts. Journal of Endocrinology 102 281-286. 
Chang CL, Roh J \& Hsu SYT 2004 Intermedin, a novel calcitonin family peptide that exists in teleosts as well as in mammals: a comparison with other calcitonin/intermedin family peptides in vertebrates. Peptides 25 1633-1642.

Chen Y, Shyu J-F, Santhanagopal A, Unoue D, David J-P, Dixon SJ, Horne WC \& Baron R 1998 The calcitonin receptor stimulates Shc tyrosine phosphorylation and Erk1/2 activation. Journal of Biological Chemistry 273 19809-19816.

Copp DH \& Cheney BA 1962 Calcitonin: a hormone from the parathyroid that lowers calcium level of the blood. Nature 193 381-382.

Cornish J, Callon KE, Bava U, Kamona SA, Cooper GJS \& Reid IR 2001 Effects of calcitonin, amylin, and calcitonin gene-related peptide on osteoclast development. Bone 29 162-168.

Dacquin R, Davey RA, Laplace C, Levasseur R, Morris HA, Goldring SR, Gebre-Medhin S, Galson DL, Zajac JD \& Karsenty G 2004 Amylin inhibits bone resorption while the calcitonin receptor controls bone formation in vivo. Journal of Cell Biology 164 509-514.

Findlay DM \& Sexton PM 2004 Calcitonin. Growth Factors 22 217-224.

Foster GV, Baghdiantz A, Kumar MA, Slack E, Soliman HA \& MacIntyre I 1964 Thyroid origin of calcitonin. Nature 202 1303-1305.

Friedman J \& Raisz LG 1965 Thyrocalcitonin: inhibitor of bone resorption in tissue culture. Science 150 1465-1467.

Goldring SR, Gorn AH, Yamin M, Krane SM \& Want JT 1993 Characterization of the structural and functional properties of cloned calcitonin receptor cDNAs. Hormone Metabolic Research 25 477-480.

Hoff AO, Catala-Lehnen P, Thomas PM, Priemel M, Rueger JM, Nasonkin I, Bradley A, Hughes MR, Ordonez N, Cote GJ et al. 2002 Increased bone mass is an unexpected phenotype associated with deletion of the calcitonin gene. Journal of Clinical Investigation 110 1849-1857.

Horwood NJ, Udagawa N, Elliot J, Grail D, Okamura H, Kurimoto M, Dunn AR, Martin TJ \& Gillespie MT 1998 Interleukin 18 inhibits osteoclast formation via $\mathrm{T}$ cell production of granulocyte macrophage colony-stimulating factor. Journal of Clinical Investigation 101 596-603.

Horwood NJ, Elliot J, Martin TJ \& Gillespie MT 2001 IL-12 alone and in synergy with IL-18 inhibits osteoclast formation in vitro. Journal of Immunology 166 4915-4921.

Humphrey MB, Ogasawara K, Yao W, Spusta SC, Daws MR, Lane NE, Lanier LL \& Nakamura MC 2004 The signaling adapter protein DAP12 regulates multinucleation during osteoclast development. Journal of Bone and Mineral Research 19 224-234.

Ibbotson KJ, Roodman GD, McManus LM \& Mundy GR 1984 Identification and characterization of osteoclast-like cells and their progenitors in cultures of feline mononuclear cells. Journal of Cell Biology 99 471-480.

Katafuchi T, Hamano K, Kikumoto K \& Minamino N 2000 Identification of second and third calcitonin receptor-stimulating peptides in porcine and brain. Biochemical and Biophysical Research Communications 308 445-451.

Katafuchi T, Kikumoto K, Hamano K, Kangawa K, Matsuo H \& Minamino N 2003 Calcitonin receptor-stimulating peptide, a new member of the calcitonin gene-related peptide family. Journal of Biological Chemistry 278 12046-12054.

Katafuchi T, Hamano K \& Minamino N 2004 Identification, structural determination, and biological activity of bovine and canine calcitonin receptor-stimulating peptides. Biochemical and Biophysical Research Communications 313 74-79.

Kawasaki H, Springett GM, Mochizuki N, Toki S, Nakaya M, Matsuda M, Housman DE \& Grabiel AM 1998 A family of cAMP-binding proteins that directly activate Rap1. Science 282 2275-2279.

Kim N, Takami M, Rho J, Josien R \& Choi YV 2002 A novel member of the leukocyte receptor complex regulates osteoclast differentiation. Journal of Experimental Medicine 195 201-209.

Koga T, Inui M, Inoue K, Kim S, Suematsu A, Kobayashi E, Iwata T, Ohnishi H, Matozaki T, Kodama Tet al. 2004 Costimulatory signals mediated by the ITAM motif cooperate with RANKL for bone homeostasis. Nature 428 758-763.

Laroche-Joubert N, Marsy S, Michelet S, Imbert-Teboul M \& Doucet A 2002 Protein kinase A-independent activation of ERK and H, K-ATPase by cAMP in native kidney cells. Journal of Biological Chemistry 277 18598-18604.

Lee SK, Goldring SR \& Lorenzo JA 1995 Expression of the calcitonin receptor in bone marrow cell cultures and in bone: a specific marker of the differentiated osteoclast that is regulated by calcitonin. Endocrinology 136 $4572-4581$.
Lee SH, Rho J, Jeong JD, Sul JY, Kim T, Kim H, Kung JS, Miyamoto T, Suda T, Lee SK et al. 2006 v-ATPase vo subunit d2-deficient mice exhibit impaired osteoclast fusion and increased bone formation. Nature Medicine $\mathbf{1 2}$ 1403-1409.

Lerner UH 2004 New molecules in the tumor necrosis factor ligand and receptor superfamilies with importance for physiological and pathological bone resorption. Critical Reviews in Oral Biology and Medicine 15 64-81.

Lin HY, Harris TL, Flannery MS, Aruffo A, Kaji EH, Gorn A, Kolakowski LF Jr, Lodish HF \& Goldring SR 1991 Expression cloning of an adenylate cyclasecoupled calcitonin receptor. Science 254 1022-1024.

Mócsai A, Humphrey MB, van Ziffle JAG, Hu Y, Burghardt A, Majumdar S, Lanier LL, Lowell CA \& Nakamura MC 2004 The immunomodulatory adapter proteins DAP12 and $F_{c}$ receptor $\gamma$-chain $\left(F_{C} R \gamma\right)$ regulate development of functional osteoclasts through the Syk tyrosine kinase. PNAS 101 6158-6163.

Moreno JL, Kaczmarek M, Keegan AD \& Tondravi M 2003 IL-4 suppresses osteoclast development and mature osteoclast function by a STAT6dependent mechanism: irreversible inhibition of the differentiation program activated by RANKL. Blood 102 1078-1086.

Nicholson GC, Moseley JM, Sexton PM, Mendelsohn FA \& Martin TJ 1986 Abundant calcitonin receptors in isolated rat osteoclasts. Biochemical and autoradiographic characterization. Journal of Clinical Investigation $\mathbf{7 8}$ 355-360.

Paloneva J, Mandelin J, Kiialainen A, Böhling T, Prudlo J, Hakola P, Haltia M, Konttinen YT \& Peltonin L 2003 DAP12/TREM2 deficiency results in impaired osteoclast differentiation and osteoporotic features. Journal of Experimental Medicine 198 669-675.

Purdue BW, Tilakaratne N \& Sexton PM 2002 Molecular pharmacology of the calcitonin receptor. Receptors and Channels 8 243-255.

Quinn JMW, Morfis M, Lam MHC, Elliott J, Karsogiannis V, Williams ED, Gillespie MT, Martin TJ \& Sexton PM 1999 Calcitonin receptor antibodies in the identification of osteoclasts. Bone 25 1-8.

Roach T, Slater S, Koval M, White L, McFarland EC, Okumura M, Thomas M \& Brown E 1997 CD45 regulates Src family member kinase activity associated with macrophage integrin-mediated adhesion. Current Biology 7 408-417.

Rho J, Altmann CR, Socci ND, Merkov L, Kim N, So H, Lee O, Takami M, Brivanlou AH \& Choi Y 2002 Gene expression profiling of osteoclast differentiation by combined suppression subtractive hybridization (SSH) and cDNA microarray analysis DNA. Cell Biology 21 541-549.

Roh J, Chang CL, Bhalla A, Klein C \& Hsu SYTV 2004 Intermedin is a calcitonin/calcitonin gene-related peptide family peptide acting through the calcitonin receptor-like receptor/receptor activity-modifying protein receptor complexes. Journal of Biological Chemistry 279 7264-7274.

Roodman GD, Ibbotson KJ, MacDonald BR, Kuehl TJ \& Mundy GR 1985 1,25-dihydroxyvitamin D3 causes formation of multinucleated cells with several osteoclast characteristics in cultures of primate marrow. PNAS $\mathbf{8 2}$ 8213-8217.

de Rooij J, Zwartkruis FJT, Verheijen MHG, Cool RH, Nijman SMB, Wittinghofer A \& Bos JL 1998 Epac is a Rap1 guanine-nucleotideexchange factor directly activated by cyclic AMP. Nature 396 474-477.

Schinke T, Liese S, Priemel M, Haberland M, Schilling AF, Catala-Lehnen P, Blicharski D, Rueger JM, Gagel RF, Emeson RB et al. 2004 Decreased bone formation and osteopenia in mice lacking $\alpha$-calcitonin gene-related peptide. Journal of Bone and Mineral Research 19 2049-2056.

Shinoda K, Sugiyama E, Taki H, Harada S, Mino T, Maruyama M \& Kobayashi M 2003 Resting T cells negatively regulate osteoclast generation from peripheral blood monocytes. Bone 33 711-720.

So H, Rho J, Jeong D, Park R, Fisher DE, Ostrowski MC, Choi Y \& Kim N 2003 Microphthalmia transcription factor and PU.1 synergistically induce the leukocyte receptor osteoclast-associated receptor gene expression. Journal of Biological Chemistry 278 24209-24216.

Takahashi N, Udagawa N, Takami M \& Suda T 2002 Cells of bone: osteoclast generation. In Principles of Biology, 2, pp 109-126. Eds JP Bilezikian, LG Raisz \& GA Rodan. San Diago: Academic Press.

Takayanagi TH, Ogasawara K, Hida S, Chiba T, Murata S, Sato K, Akinori T, Yokochi T, Oda H, Tanaka K et al. 2000 T-cell mediated regulation of osteoclastogenesis by signalling cross-talk between RANKL and IFN- $\gamma$. Nature 408 600-605. 
Takeshita S, Kaji K \& Kudo A 2000 Identification and characterization of the new osteoclast progenitor with macrophage phenotype being able to differentiate into mature osteoclasts. Journal of Bone and Mineral Research $\mathbf{1 5}$ $1477-1488$.

Teitelbaum SL 2000 Bone resorption by osteoclasts. Science 289 1504-1508.

Teitelbaum SL \& Ross FP 2003 Genetic regulation of osteoclast development and function. Nature Reviews. Genetics 4 638-649.

Wimalawansa SJ 1997 Amylin, calcitonin gene-related peptide, calcitonin, and adrenomedulin: a peptide superfamily. Critical Reviews in Neurobiology 11 167-239.

Yagi M, Miyamoto T, Toyama Y \& Suda T 2006 Role of DC-STAMP in cellular fusion of osteoclasts and macrophage giant cells. Journal of Bone and Mineral Metabolism 24 355-358.
Zaidi M, Inzerillo AM, Moonga BS, Bevis PJR \& Huang CLH 2002 Forty years of calcitonin - where are we now? A tribute to the work of Iain Macintyre, FRS. Bone 30 655-663.

Zhang Z, Neff L, Bothwell ALM, Baron R \& Horne WC 2002 Calcitonin induces dephosphorylation of PYK2 and phosphorylation of focal adhesion kinase in osteoclasts. Bone 31 359-365.

Received in final form 3 September 2007

Accepted 20 September 2007

Made available online as an Accepted Preprint 20 September 2007 